\title{
Transposition of the great arteries and narrowing of the aortic arch Emphasis on right ventricular characteristics
}

\author{
RUDOLF J MOENE, JAAP OTTENKAMP, $†$ ARENTJE OPPENHEIMER-DEKKER, \\ MARGOT M BARTELINGS‡ \\ From the $\nmid$ Department of Paediatric Cardiology, State University of Leiden and $\star$ Free University Hospital, \\ Amsterdam; and the $\ddagger$ Department of Anatomy and Embryology, State University of Leiden, Leiden, the Netherlands
}

SUMMARY Of 279 patients with transposition of the great arteries, $14(5 \%)$ had narrowing of the aorta, including local coarctation (6), isthmus hypoplasia (6), isthmus atresia (1), and kinking of the aorta (1). There were six deaths in 10 surgically treated patients; in addition four patients died before operation. Two of the four survivors had a subpulmonary malalignment ventricular septal defect with angiocardiographic narrowing of the right ventricular outflow tract; two had evidence of redundant muscle tissue obstructing the right ventricular outflow tract. Necropsy showed the presence of anatomical right ventricular outflow tract or inflow tract obstruction or both in all 10 cases. Outflow tract obstruction was represented by anterior displacement of the infundibular septum and ventriculoinfundibular fold (in hearts with a subpulmonary malalignment ventricular septal defect) or by redundant muscle tissue; inflow tract obstruction was represented by hypoplasia of the tricuspid valve.

It is concluded that the combination of transposition of the great arteries and narrowing of the aorta is always accompanied by right ventricular outflow or inflow tract obstruction or both; the right ventricular abnormalities are probably responsible for the presence of the aortic arch anomalies by reducing aortic flow during morphogenesis. Successful surgical treatment of this complex anomaly is feasible in selected cases.

About one half of all cases of transposition are "simple," the second half being complicated by other anomalies. ${ }^{1}$ The two commonest associated abnormalities in transposition are ventricular septal defect and left ventricular outflow tract obstruction, occurring separately or together. The incidence of a complicating obstruction of the aortic arch has been estimated to range between $4.6 \%$ and $10 \% .^{23}$ More recently, complete transposition of the great arteries with ventricular septal defect and coarctation or atresia of the aortic arch has been described as a separate anatomicoclinical entity which includes inlet or outlet right ventricular obstruction. ${ }^{4}$

The present study was carried out to define right

Requests for reprints to Dr Rudolf J Moene, Department of Paediatric Cardiology, Free University Hospital, De Boelelaan 1117, 1081 HV Amsterdam, The Netherlands.

Accepted for publication 24 August 1984 ventricular characteristics in patients with transposition of the great arteries and obstruction of the aortic arch.

\section{Patients and methods}

Two hundred and seventy nine patients with complete transposition of the great arteries were referred to the Leiden University Hospital between 1960 and 1982. Fourteen $(5 \%)$ of these patients proved to have a complicating aortic arch obstruction. Four patients died before operation and six died after a Senning procedure, a Hanlon operation, banding of the pulmonary artery, coarctation resection, or a combination of these procedures. With one exception, the patients died before 1975; the four survivors were operated on more recently.

The angiograms and heart specimens were studied with special attention to the morphology of the right 
Table 1 Clinical data of patients who underwent successful surgery

\begin{tabular}{|c|c|c|c|c|c|}
\hline \multirow[t]{2}{*}{ Case No } & \multirow{2}{*}{$\begin{array}{l}\text { Aortic arch } \\
\text { anomaly }\end{array}$} & \multicolumn{2}{|l|}{ Right ventricle } & \multirow{2}{*}{$\begin{array}{l}\text { Ventricular } \\
\text { septal defect }\end{array}$} & \multirow[t]{2}{*}{ Surgical interventions } \\
\hline & & Outflow tract & Infibw tract & & \\
\hline 1 & $\mathrm{COA}$ & $\begin{array}{l}\text { Anterior displacement of IS } \\
\text { and prominent VIF }\end{array}$ & - & $\begin{array}{c}\text { Subpulmonary } \\
\text { malalignment }\end{array}$ & $\begin{array}{l}\text { Blalock-Hanlon and banding (aged } 1 \\
\text { mnth), repair of coarctation (aged } 12 \\
\text { yrs), debanding; VSD closed; arterial } \\
\text { switch (aged } 121 / 2 \text { yrs), closure of residual } \\
\text { VSD (aged } 12 \frac{1}{2} \text { yrs) }\end{array}$ \\
\hline 2 & TH & $\begin{array}{l}\text { Anterior displacement of IS } \\
\text { and prominent VIF }\end{array}$ & - & $\begin{array}{c}\text { Subpulmonary } \\
\text { malalignment }\end{array}$ & VSD closed; arterial switch (aged 3 mnths) \\
\hline $\begin{array}{l}3 \\
4\end{array}$ & $\begin{array}{l}\text { TH } \\
\text { Kinking }\end{array}$ & $\begin{array}{l}\text { Prominent VIF } \\
\text { Prominent IS and VIF }\end{array}$ & - & - & $\begin{array}{l}\text { Senning operation (aged } 6 \text { mnths) } \\
\text { Mustard operation (aged } 1 \text { yr) }\end{array}$ \\
\hline
\end{tabular}

COA, coarctation of the aorta; IS, infundibular septum; TH, tubular isthmus hypoplasia; VIF, ventriculoinfundibular fold; VSD, ventricular septal defect.

ventricle; angiograms of patients with transposition but without aortic arch anomalies and 15 normal heart specimens from subjects of different ages served as controls. The ventricular septal defects were classified according to Soto $e t a^{5}$; in addition we used the term "subpulmonary malalignment" for defects with rightwards shifting of the infundibular septum and overriding of the pulmonary artery. The right ventricular muscular structures were described according to the terminology proposed by Anderson et al. ${ }^{6}$

Tubular hypoplasia of the aortic isthmus was defined as a combination of abnormally great length and small diameter of that segment according to the criteria given by Moulaert et al. ${ }^{7}$

Using Hegar dilators, the tricuspid valve annulus was measured in relation to the mitral valve annulus. The tricuspid valve was considered to be hypoplastic if its diameter was $<0.8$ of that of the mitral valve. ${ }^{8}$

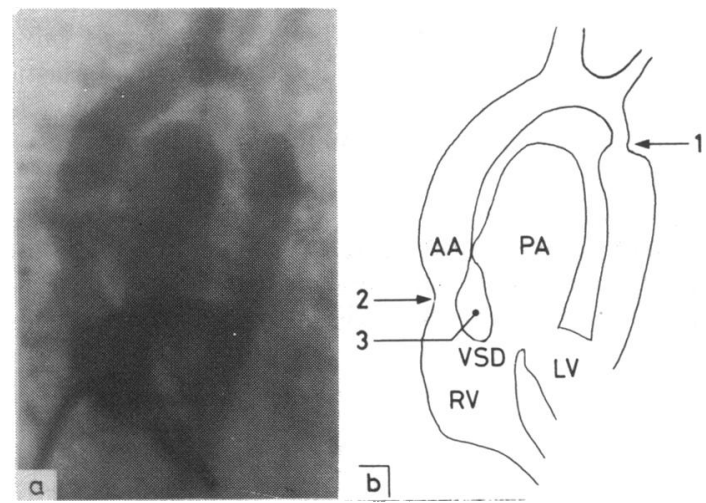

Fig. 1 (a) Lateral angiocardiogram in neonate (case 2) with transposition of great arteries, subpulmonary malalignment ventricular septal defect, isthmus hypoplasia, and mild subaortic narrowing. (b) Schematic drawing of the angiocardiogram. $A A$, ascending aorta; $L V$, left ventricle; $R V$, right ventricle; $P A$, pulmonary artery; VSD, ventricular septal defect; 1 , isthmus hypoplasia; 2, mild subaortic narrowing; 3, infundibular septum.

\section{Results}

\section{SURVIVORS}

Four patients were alive and well six months to five years after operation (Table 1). In two of these patients (cases 1 and 2) a subpulmonary malalignment ventricular septum defect was closed, and the other two had an intact ventricular septum. The subpulmonary malalignment defects were angiocardiographically characterised by overriding of the pulmonary artery; in addition, right ventriculography showed muscular subaortic stenosis caused by an anteriorly displaced infundibular septum and prominence of the ventriculoinfundibular fold (Figs. 1 and 2).

The angiocardiogram of the patient with kinking of the aorta and an intact ventricular septum (case 4)

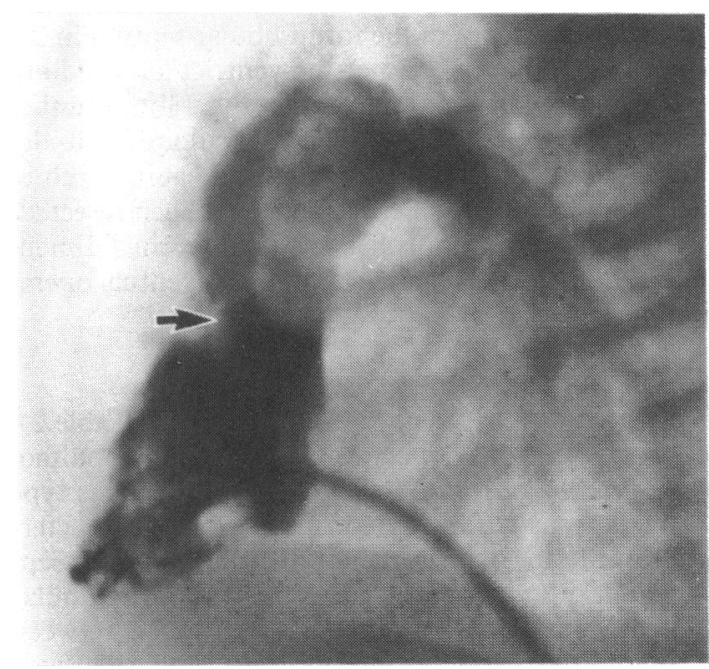

Fig. 2 Lateral right ventriculogram in neonate (case 1) with transposition of great arteries, subpulmonary ventricular septal defect, and local coarctation (not visible in this frame). Note subaortic stenosis (arrow) and relatively anterior position of wide pulmonary artery. 


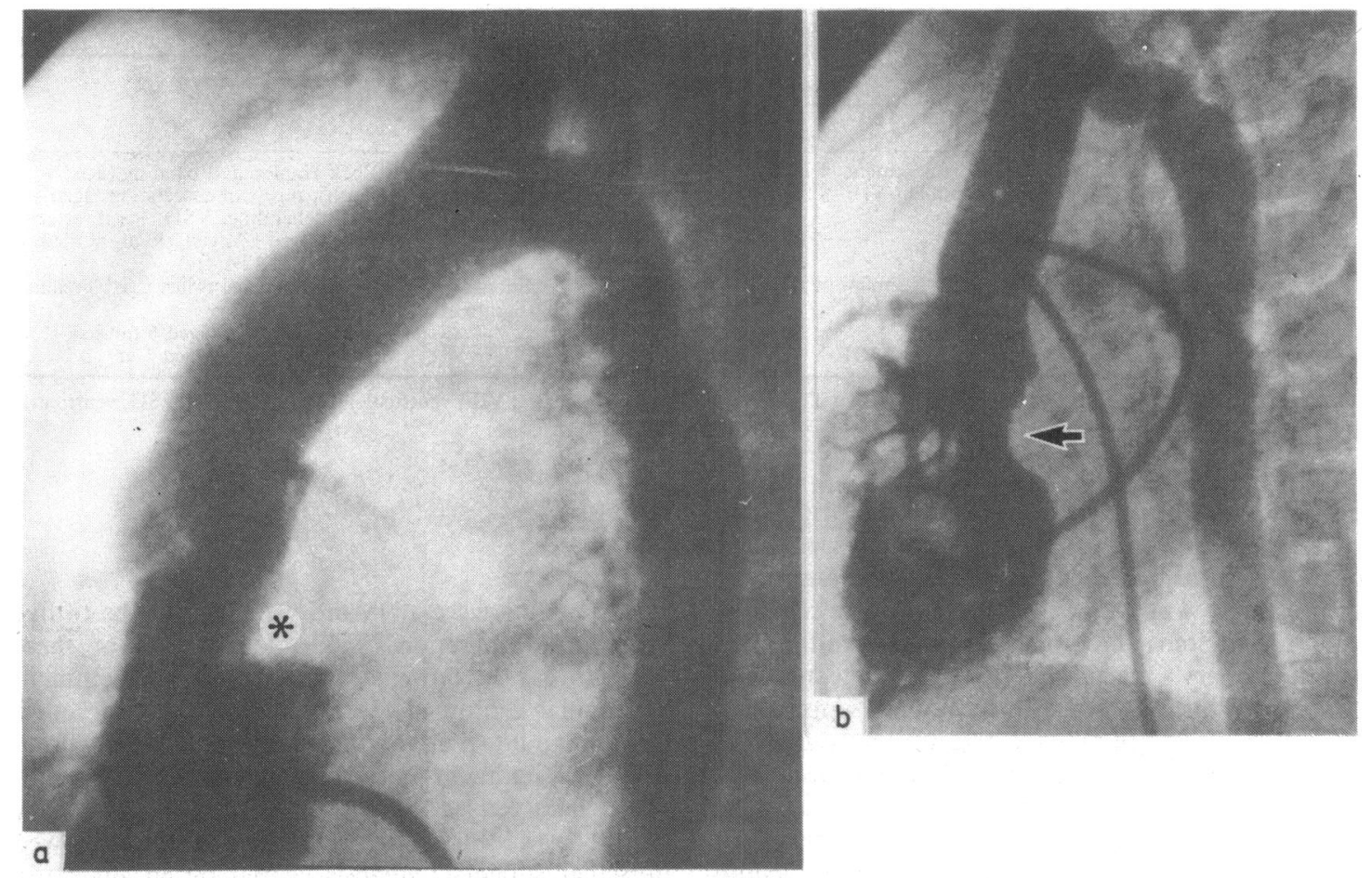

Fig 3 (a) Lateral right ventriculogram in a 1 year old child (case 4) with transposition of the great arteries and kinking of the aorta. Note the prominence of the infundibular septum (asterisk); frame taken during ventricular diastole. (b) Left oblique view in the same patient; frame taken during ventricular systole. Note the subaortic stenosis (arrow) caused by infundibular septum and ventriculoinfundibular fold.

showed prominence of the infundibular septum in the lateral view (Fig. 3a) and of the ventriculoinfundibular fold in the left oblique view (Fig. 3b). Another example of prominence of the ventriculoinfundibular fold is shown in Fig. 4. Regarding the aortic arch of the survivors, one local coarctation has been resected, one hypoplastic isthmus has grown to normal dimensions, and two of the patients await an eventual operation.

\section{NON-SURVIVORS}

Ten patients died before or after operation (Table 2). Six of the necropsy specimens showed a subpulmonary ventricular septal defect (cases 5-10). This type of defect is, as has been described before, ${ }^{9}$ characterised by anterior displacement of the infundibular septum and prominence of the ventriculoinfundibular fold; this results in a reduction in distance between these structures and the anterior right ventricular wall and thus in narrowing of the outflow tract (Fig. 5). This close relation between (type of) ventricular septal defect and outflow tract narrowing was absent in the other four specimens, of which one showed a perimembranous trabecular defect, one a very small muscular inlet defect, and two an intact septum. In these four cases either redundant muscle tissue obstructed the outflow tract (three hearts) or the inflow tract was obstructed by a hypoplastic tricuspid valve or both. Two cases (cases 13 and 10) of hypoplastic tricuspid valves and redundant outflow tract muscle tissue (a prominent ventriculoinfundibular fold and a trabecula in front of the aortic ostium) are shown in Figs. 6 and 7.

Valid catheterisation data were available for eight patients. In only one of these patients a pressure gradient (of $30 \mathrm{mmHg}$ ) was present across the right ventricular outflow tract.

\section{Discussion}

The findings in this study show that in all cases of transposition of the great arteries and narrowing of the aorta, anatomical right ventricular outflow or inflow tract obstruction or both are present. Milanesi et al came to the same conclusion, ${ }^{4}$ and we agree with these authors that unequal partitioning of the blood flow as a consequence of right ventricular obstruction may be the fetal pathogenetic mechanism for the 


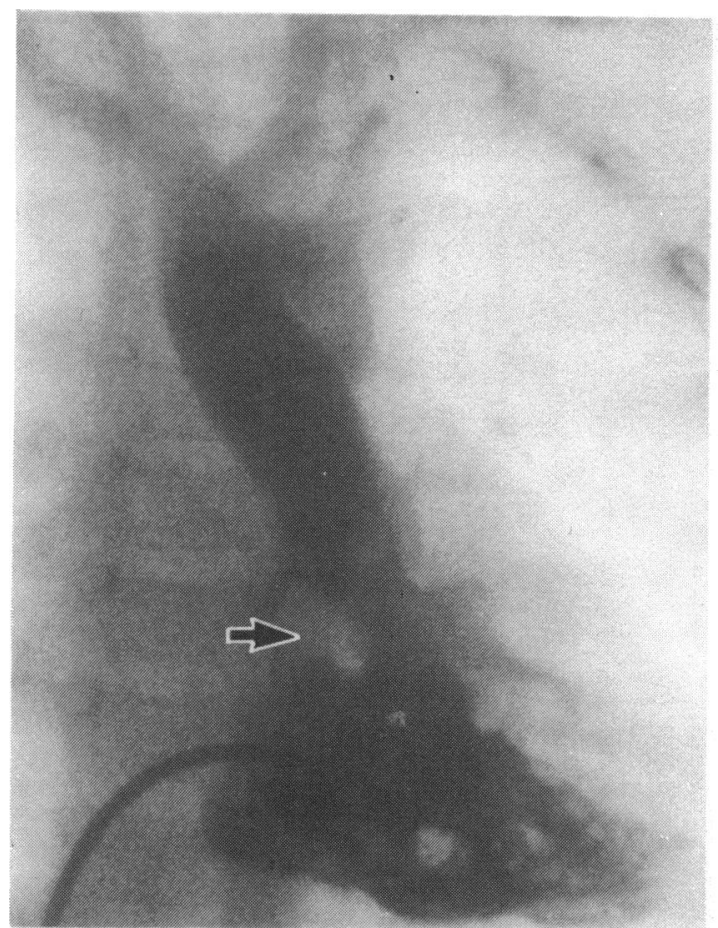

Fig. 4 Right ventriculogram in 8 month old child (case 12) with transposition of the great arteries and local coarctation, which is hidden behind the ascending aorta in this frontal view. Note the subaortic narrowing by undue prominence of the ventriculoinfundibular fold (arrow).

underdevelopment of the aortic arch, as postulated for left ventricular outflow tract obstruction in normally related great arteries. ${ }^{1011}$ Eight out of 14 patients proved to have a subpulmonary malalignment ventricular septal defect with anterior and rightward displacement of the infundibular septum. A rightward

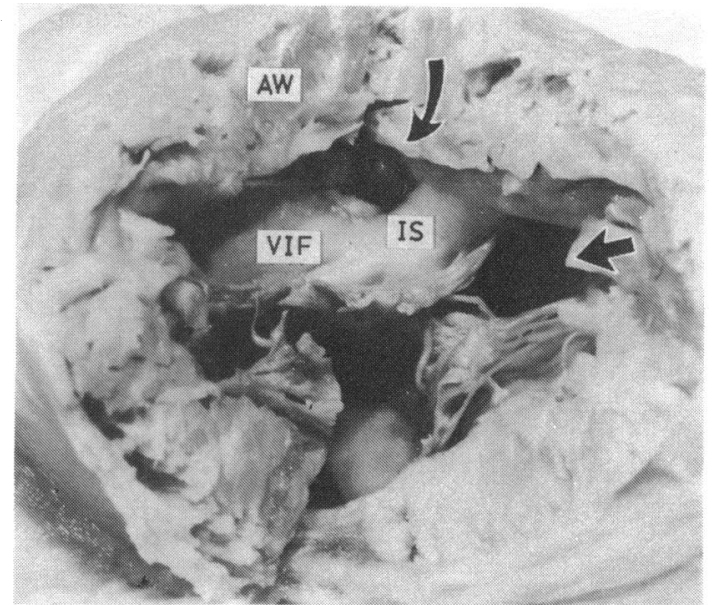

Fig. 5 Morphological appearance of the right ventricle in a patient (case 5) with subpulmonary ventricular septal defect (arrow). Anterior displacement of the infundibular septum (IS) and prominence of the ventriculoinfundibular fold (VIF) narrow the outflow tract (curved arrow). AW, anterior wall of the right ventricle.

shift of the infundibular septum is also an essential feature of double outlet right ventricle with subpulmonary ventricular septal defect; the difference between transposition and double outlet right ventricle is evident by the degree of rightward shifting of the infundibular septum and thus by the degree of pulmonary artery overriding. Since the frequent concurrence of double outlet right ventricle and aortic arch anomalies has been established before (Kurosawa $\mathrm{H}$, van Mierop LHS. World Congress of Paediatric Cardiology, London, 1980, abstract No 339), ${ }^{12-14}$ we selected for the present study cases of transposition according to the $50 \%$ rule-that is, in our cases the pulmonary artery was mainly committed to the left ventricle.

Table 2 Anatomical features of cases examined at necropsy

\begin{tabular}{|c|c|c|c|c|c|}
\hline \multirow[t]{2}{*}{ Case No } & \multirow[t]{2}{*}{ Age } & \multirow{2}{*}{$\begin{array}{l}\text { Aortic arch } \\
\text { anomaly }\end{array}$} & \multicolumn{2}{|l|}{ Right ventricle } & \multirow[t]{2}{*}{$V S D$} \\
\hline & & & Outfiow tract & Inflow tract & \\
\hline 5 & 5 mnth & TH & Anterior displacement of IS and VIF & - & Subpulmonary malalignment \\
\hline 6 & $4 \mathrm{mnth}$ & TH & Anterior displacement of IS and VIF & - & Subpulmonary malalignment \\
\hline 7 & 2 wk & TH & Anterior displacement of IS and VIF & - & Subpulmonary malalignment \\
\hline 8 & $1 \frac{1}{2} \mathrm{yr}$ & COA & Anterior displacement of IS and VIF & - & Subpulmonary malalignment \\
\hline 9 & 1 mnth & $\mathrm{COA}$ & Anterior displacement of IS and VIF & - & Subpulmonary malalignment \\
\hline 10 & 1 mnth & COA & Anterior displacement of IS and VIF & $\begin{array}{l}\text { Hypoplastic TV } \\
\text { Hypoplastic TV }\end{array}$ & Subpulmonary malalignment \\
\hline 12 & $8 \mathrm{mnth}$ & $\mathrm{COA}$ & Prominent VIF & & \\
\hline 13 & $2 \mathrm{mnth}$ & TH & Trabecula ventral to aortic ostium & $\begin{array}{l}\text { Hypoplastic TV } \\
\text { and right }\end{array}$ & Small muscular inlet \\
\hline 14 & 3 mnth & $\begin{array}{l}\text { Isthmus } \\
\text { atresia }\end{array}$ & Prominent IS and VIF & Hypoplastic TV & Perimembranous trabecula \\
\hline
\end{tabular}

COA, coarctation of the aorta; TH, tabular isthmus hypoplasia; IS, infundibular septum; VIF, ventriculoinfundibular fold; VSD, ventricular septal defect; TV, tricuspid valve. 


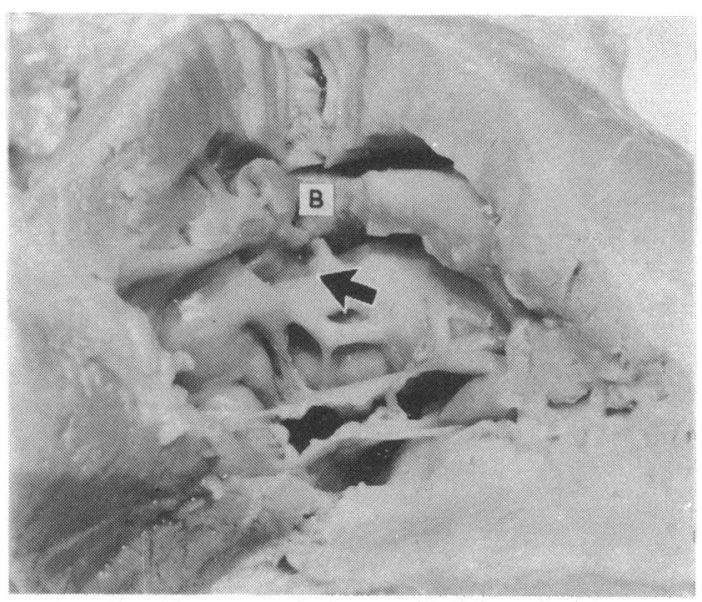

Fig. 6 Morphological specimen in case 13 showing narrowing of the right ventricular outflow tract (arrow) by an aberrant hypertrophic muscle bundle $(B)$ in front of the aortic ostium. Note the hypoplasia of the tricuspid valve.

In a previous anatomical study we found aortic arch anomalies in $35 \%$ of hearts with transposition of the great arteries and right ventricular outflow tract obstruction. ${ }^{9}$ It should be noted that the diagnosis of right ventricular outflow tract obstruction is an estimation, and in that as well as in the present study it means an obstruction relative to normal. In this respect it is important to realise that in only a few patients with an obvious, angiocardiographically demonstrated, narrow subaortic area may a pressure gradient be recorded across it. ${ }^{4915}$ Nevertheless, a poorly expanded or relatively narrow subaortic conus should be viewed as potentially obstructive according to Freedom et al. ${ }^{15}$ In our view more studies of the relation between anatomical right ventricular obstructions and catheterisation data are needed to establish the functional implications and natural history of these anomalies.

Milanesi et al suggest that the combination of transposition of the great arteries and coarctation of the aorta is not so rare and that the clinical manifestations and the pathological findings of this association are sufficiently distinctive as to be considered a separate nosographic entity among transposition of the great arteries. ${ }^{4}$ According to these authors, the entity should include the following morphological features: (a) a ventricular septal defect, mostly subpulmonary; (b) underdevelopment of the right ventricular trabecular component; and (c) right ventricular outflow or inflow obstruction.

Our study confirms the presence of angiocardiographic or anatomical outflow or inflow obstruction or both in all cases. Nevertheless, underdevelopment of the right ventricle was diagnosed only once as a sepa-

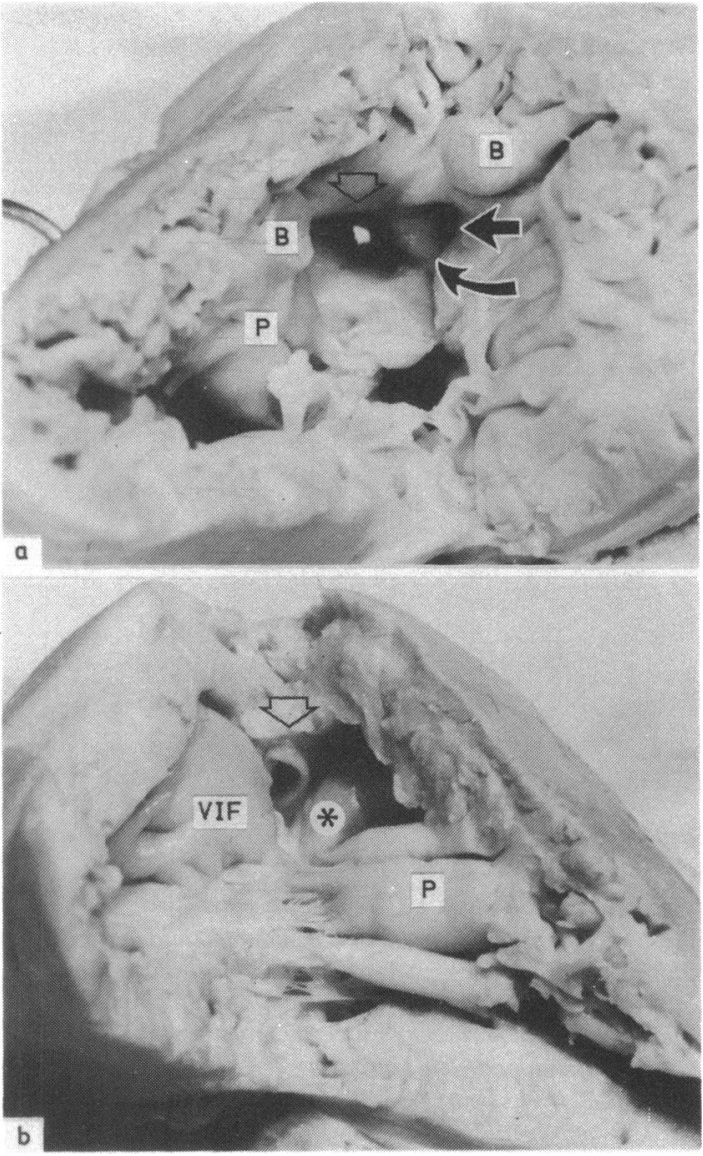

Fig. 7 Morphological appearance of the right ventricle in a patient (case 10) with subpulmonary ventricular septal defect (arrow). (a) A displaced infundibular septum (curved arrow) narrows the outflow tract (open arrow). A cut aberrant muscle bundle $(B)$ crosses the right ventricular cavity. The hypoplastic tricuspid valve is connected with an abnormal, thick parietal papillary muscle group $(P)$. In this view the ventricle is opened with an incision along the ventricular septum. (b) The same right ventricle opened by a more parietal incision showing the outflow tract (open arrow), which is narrowed by a displaced infundibular septum (asterisk) and a very prominent ventriculoinfundibular fold (VIF). Note the abnormal thick papillary muscles $(P)$.

rate feature; in all other cases the trabecular part was not hypoplastic, although in some cases outflow tract obstructing muscle bundles protruded into the trabecular part as well, thus reducing the trabecular lumen.

Another difference between our findings and those of Milanesi et al applies to the obligatory presence of a ventricular septal defect in their cases; in our patients four $(28 \%)$ proved to have an intact ventricular sep- 
tum. Since, in addition, the type of aortic arch anomaly may differ (from atresia via tubular hypoplasia and local coarctation to kinking of the aorta) we conclude that the variety of these findings does not justify the definition of a nosographic entity.

This conclusion implies that a general prognosis cannot be given for the group as a whole and that the surgical results depend on the presence or absence of an intact ventricular septum and the type and degree of aortic arch anomaly. In this respect it is important to realise that, although most cases had distinct narrowing of the aorta, in other cases the narrowing may be mild; this was the case in some patients with tubular hypoplasia of the isthmus, in one of which the isthmus grew spontaneously to normal dimensions.

The hospital mortality has been high in the earlier years of our experience; recent results support the feasibility of successful surgical treatment. In this context, however, the maintained systemic right ventricular blood pressure may trigger hypertrophy, eventually resulting in progression of the outflow obstruction; as we indicated before ${ }^{9}$ this progression might be prevented by performing an arterial switch procedure with resulting normalisation of right ventricular pressure.

Indications for surgical treatment of right ventricular outflow and inflow tract obstruction should be based on the results of functional and natural history studies, which have not been performed as yet.

This study was supported in part by The Netherlands Heart Foundation, The Hague, The Netherlands.

\section{References}

1 Shaher RM. Complete transposition of the great arteries. New York: Academic Press, 1973: 57.

2 Liebman J, Cullum L, Belloc NB. Natural history of transposition of the great arteries. Anatomy and birth and death characteristics. Circulation 1969; 40: 237-62.

3 Schumacher G, Lorenz HP, Schreiber R, Mocellin R, Sebening F, Bühlmeyer K. Operative Therapie bei kom- plexen Formen der kompletten Transposition der groszen Arterien. Herz 1981; 6: 344-51.

4 Milanesi O, Thiene G, Bini RM, Pellegrino PA. Complete transposition of great arteries with coarctation of aorta. Br Heart $\mathcal{F}$ 1982; 48: 566-71.

5 Soto B, Becker AE, Moulaert AJ, Lie JT, Anderson RH. Classification of ventricular septal defects. $\mathrm{Br} \mathrm{Heart} \mathcal{F}$ 1980; 43: 332-43.

6 Anderson RH, Becker AE, van Mierop LHS. What should we call the "crista"? Br Heart f 1977; 39: 856-9.

7 Moulaert AJ, Bruins CL, Oppenheimer-Dekker A. Anomalies of the aortic arch and ventricular septal defects. Circulation 1976; 53: 1011-5.

8 Peter K, Wetzel G. Heiderich F, eds. Handbuch der Anatomic des Kindes, Band II. Munich: JF Bergmann Verlag, 1938: 290-1.

9 Moene RJ, Oppenheimer-Dekker A, Bartelings MM. Anatomic obstruction of the right ventricular outflow tract in transposition of the great arteries. Am $\mathcal{F}$ Cardiol 1983; 51: 1701-4.

10 Rudolph AM, Heymann MA, Spitznas V. Hemodynamic considerations in the development of narrowing of the aorta. Am $\mathcal{F}$ Cardiol 1972; 30: 514-25.

11 Moene RJ, Oppenheimer-Dekker A, Moulaert AJ, Wenink ACG, Gittenberger-de Groot AC, Roozendaal $H$. The concurrence of dimensional aortic arch anomalies and abnormal left ventricular muscle bundles. Pediatr Cardiol 1982; 2: 107-14.

12 Neufeld HN, Randall PA. Double outlet right ventricle. In: Moss AJ, Adams FH, Emmanouillides GC, eds. Heart disease in infants, children and adolescents. Baltimore: Williams and Wilkins, 1968: 355-67.

13 Wilcox BR, Ho SY, Macartney FJ, Becker AE, Gerlis LM, Anderson RH. Surgical anatomy of double-outlet right ventricle with situs solitus and atrioventricular concordance. $\mathcal{F}$ Thorac Cardiovasc Surg 1981; 82: 405-17.

14 Wilkinson JL, Wilcox BR, Anderson RH. Anatomy of double-outlet right ventricle. In: Anderson RH, Macartney FJ, Shinebourne EA, Tynan M, eds. Paediatric cardiology. vol 5. New York: Churchill Livingstone, 1983: 397-6.

15 Freedom RM, Culham JAG, Rowe RD. Angiocardiography of subaortic obstruction in infancy. $A \mathcal{F}$ 1977; 129: $813-24$. 